\title{
The evaluation of chosen body posture parameters in children with scoliosis - own materials
}

\author{
Zbigniew Śliwiński ${ }^{*}$, Wojciech Kufel ${ }^{1}$, Bartłomiej Halat ${ }^{1}$, Beata Michalak¹, Danuta Śliwińska', Grzegorz Śliwiński \\ From 11th International Conference on Conservative Management of Spinal Deformities - SOSORT 2014 \\ Annual Meeting \\ Wiesbaden, Germany. 8-10 May 2014
}

\section{Introduction}

Treatment of children with scoliosis requires the monitoring and evaluation of posture parameters. The raster stereographic method can be used at any time to observe the therapy progress due to its harmlessness towards the child.

\section{Material and methods}

We evaluated 140 children with idiopathic scoliosis treated by the FED method at the Rehabilitation Centre in Zgorzelec. The children were assessed by the 4D DIERS Formetric III at the beginning and the end of the month of the stay. Some of the patients were evaluated sixmonths after the FED treatment. One of the parameters selected to assess the therapy outcome is the rotation of the trunk area beginning at the apex deriving from radiography.

\section{Results}

Preliminary results in both groups, the group assessed after a month and the group assessed after six-months, reveal a reduction of the rotation parameter by an average of 40 .

\section{Conclusions}

After a preliminary analysis of the trunk posture in children with idiopathic scoliosis assessed by DIERS Formetric III 4D, the raster stereographic method can be considered a fast, secure way to follow-up the outcome of the FED therapy.

'Physiotherapy Center Zgorzelec, Zgorzelec, Poland

Full list of author information is available at the end of the article

\section{Authors' details}

${ }^{1}$ Physiotherapy Center Zgorzelec, Zgorzelec, Poland. ${ }^{2}$ Dresden University of Technology - Institute of Biomedical Engineering, Dresden, Germany.

Published: 4 December 2014

doi:10.1186/1748-7161-9-S1-P13

Cite this article as: Śliwiński et al.: The evaluation of chosen body

posture parameters in children with scoliosis - own materials. Scoliosis 2014 9(Suppl 1):P13.
Submit your next manuscript to BioMed Central and take full advantage of:

- Convenient online submission

- Thorough peer review

- No space constraints or color figure charges

- Immediate publication on acceptance

- Inclusion in PubMed, CAS, Scopus and Google Scholar

- Research which is freely available for redistribution

Submit your manuscript at www.biomedcentral.com/submit
() Biomed Central 